\title{
THE MODERN ENTERPRISE - SUCCESSOR OF BUSINESS ORGANIZATION FORMS IN ANCIENT ROME AND MEDIEVAL EUROPE
}

\author{
Anca Păcală \\ Faculty of Electrical Engineering and Information Technology, University of Oradea, \\ Oradea, Romania \\ ancapacala@yahoo.com
}

\begin{abstract}
In recent years, researchers and practitioners are increasingly interested in the role and influence of the forms of business organization on the economy and society. Interpretations of the role of companies in the modern period, ranging from enthusiastic support (as the most important invention of capitalism, an explanation of the Western civilization's expansion) to moderate and often critical positions, where the company is seen as a solution, not necessarily optimal, to market imperfections. On the other hand, we often ponder upon the explanation of political, administrative and infrastructural success of ancient Rome: the state or the enterprise (the private initiative)? Closer to our time, we rediscover with amazement that the "dark" Middle Ages are not at all dark and lacking in progress, at least in terms of capitalist organization and logic. The development of trade in the two poles of medieval Europe (the Mediterranean and the BaltoScandinavian area), of industry and trade in the North-Western quadrant (Flanders and neighbouring regions), was concurrent with the improvement of organizational forms of business, with the diversity and flexibility of entrepreneurial or even corporate frameworks. Of course, the study of historical sources (ancient or medieval) cannot provide direct answers or solutions to the questions of modern society, because the challenges of today are rather different to those of the past. On the other hand, understanding history can help companies to build a more complete and a wiser enterprise functionality and role in the modern society, to reformulate the questions and to find new solutions. Our paper, with a clear juridical perspective on economic history, focuses on the organization of firms in ancient Rome and medieval Europe, tries to provide examples, useful interpretations and diverse solutions to the problems of contemporary society and economy.
\end{abstract}

Keywords: business organization; company; Rome; Middle Age.

JEL classification: B11; L22; N80.

\section{Introduction}

This article is based on the identification and analysis of the time of appearance of the first forms of business organization within a given historical framework. As heirs to the incomparable Roman law, we cannot ignore its influence in organizing production and trade, establishment and liquidation of companies, legal capacity or legal protection. Modern society discovers with astonishment striking similarities between proto-corporate forms of organization in Rome or Ancient India, differences or different directions taken by the business world in the Middle East, or the essential limitations of the forms of business organization in ancient Rome and modern times. This leads us to the conclusion that contemporary firms, in their diversity, are successors, in varying proportions, of both Roman law and, particularly, of the experiences and distinct foundations of the Middle Ages and the modern period. 


\section{Organization of businesses in ancient Rome: from the societas and familia to societas publicanorum}

Ancient Rome is known not only by its military and politically-administrative expansion, but also for incredible achievements in infrastructure, urbanization and commercial facilities. The famous Roman roads and aqueducts, construction of temples and financing military expeditions imposed a rigorous corporate organization and, especially, capital intensive. It is likely that the common point of research, which, by addressing multiple perspectives (engineering, legal or economic), are trying to understand the corporate mechanism (the so-called corporate law) of business organization and its role in the Roman society. However, according to Hansmann et al. (2006), with the exception of a small group of large firms offering services only to the Roman state, most of the new companies seem to not have been endowed with legal personality, protected by law.

The simplest form of business organization in ancient Rome was the societas, a term often translated by "partnership" because it refers to an agreement between Roman citizens to share the profits or losses of an enterprise. However, these societas had little in common with contemporary forms of partnership, by missing the aspect of reciprocity. The rule, which now appears as the default of shared responsibility in the face of a debt, to the Romans it was a rather "pro-rata" liability (Hansmann, et al., 2006). Roman law did not distinguish between societas assets and liabilities on the one hand, and those of its members on the other, a distinction that characterizes a modern partnership (Crook 1967: 233). Most societas in ancient Rome had a limited membership, a situation that contrasts sharply with the effective partnership forms assumed since the Middle Ages (Pacala, 2012). It is possible that other organization (such as those to be discussed below, familia and peculium) would have covered better the business needs of Roman society.

Like the modern family, the Roman family appears to be a complete entity: lenders entering into transactions with family members who were not authorized to transact on behalf of the family, could not have any claim to the family wealth (Pacala, 2011). The Roman family was consisted of the oldest male person, the so called pater familias, his wife, unmarried children, his slaves, and all his descendants' adult male members of their households (Johnston, 1932). Pater familias formally had ownership of all the family's goods, regardless of their origin. These attributes made Roman families very comprehensive, and, in terms of creditors, solvent. The succession of generations ensured the continuity of the family and responsibility in face of these creditors.

Concentration of wealth, the pyramidal aspect of management, the strong ties between its members ensured to the Roman family a remarkable economic power, enabling it to engage in large commercial and industrial businesses. These businesses could be supported by a family without recourse to other "shareholders' or partners (more or less known), and thus without using complicated contracts. However, with the exception of outstanding cases, the majority of Roman commercial companies were operating at a small scale in workshops or the homes of artisans.

Understanding the third category of commercial and business organization - the peculium - is based on the fact that the institution of slavery was extended in ancient Rome. Roman families frequently delegated the commercial activity to their slaves. They considered that involvement in business was somewhat demeaning or that some slaves had outstanding commercial skills (especially due to their origin - Greece or the Middle East). A common practice was to provide a slave with a series of assets called peculium that were to be used in a business. These assets plus any improvements and acquisitions remain formally in the property of the slave's master. He would receive regular payment from the slave trader or a hefty amount if the slave was sold, plus the return of existing assets (peculium). Peculium enterprises showed a high degree of asset partitioning (Hansmann and Kraakman, 1999).

The fact that the slave's master did not participate in the peculium's business management, left creditors void of the possibility to turn upon him in case of failure of the 
enterprise. The master's liability was limited to the value of the peculium: otherwise the liability was of the slave. In short, slave-managed peculium businesses, who were a mainstay of trade in the Roman period, led to an aberrant partitioning asset, with an increased risk for creditors of the company (Pacala, 2012). To our knowledge, this is a model that has not occurred in other social organizations or commercial actions in the past and even today.

Despite this general lack of legal personality in the Roman business world, we find a type of firms with several owners, known as societas publicanorum (tradable limited partnership). They consist of groups of investors, known as the publicani, who are bidding to obtain state contracts: construction of public works, supply of weapons or collection of fees. The principal investor in the group pledges its properties as collateral for performance of the contract, while other investor-participants are involved in running and exercising control activities (being fully responsible for the debts of the company). There were also partners who enjoyed limited liability but had no right to control the business (Malmendier, 2006). By the first century BC, the largest societas publicanorum were comparable in size and internal structure to modern companies. Societas Publicanorum enjoyed a legal personality protected by law, at least in terms of the relationship with partners with limited powers (Malmendier, 2006). But the similarities do not include the protection of minority shareholders or stakeholders (in terms of modern-day approach). Because Societas Publicanorum provided only to the state, and not to private entities, the Roman state had an interest in the effective and honest management of that firm and would have severely punished any serious abuse inside or outside it (Malmendier, 2005).

Although the Roman Commercial Law did not encourage the idea of a legal entity able to represent the interests of shareholders, we can say that the Romans clearly understood the concept of legal person both in its weak variants (societas or peculium) and in a powerful form (societas publicanorum), up to recognizing the non-commercial legal entities, such as municipalities and non-profit organizations. However, societas publicanorum were not been used for private businesses. Explanations are either economic: the cost - benefit ratio was too small, or political: the envy of emperors on the wealth and influence of the publicani (Pacala, 2012). Gradually, in the $3^{\text {rd }}$ and $4^{\text {th }}$ century of our era, every element of business organization and protection of parties, freedom and initiative in business has been ignored or distorted (Pacala, 2011). The collapse of the Western Roman Empire, followed by the onset of the Middle Ages, postponed by centuries the economic recovery and the emergence of a business based on the existence of legal entities protected by law.

\section{Enterprises and forms of association in the Middle Ages business}

After an extremely troubled period, the $11^{\text {th }}$ and $12^{\text {th }}$ centuries' Europe was the place of silent transformations, but of paramount importance for the course of events in centuries to come. It is the "commerce revolution" linked to some great events, so that it is difficult to argue to what extent are they the causes or effects of the process: the cessation of barbarian invasions, the replacing of the conflicts with complementarity of production, a relative peace and a regress of mortality, the commercial and cultural side of the crusades and so forth. Finally, we are witnessing the birth or the "revival" of cities. Whether are newly founded settlements or conurbations, or old ones, their primacy is given by the economic function (Le Goff, 1994).

However, not all European regions show the same intensity of commercial and demographic revival. Researchers such as Braudel (1985) or Le Goff (1994) identify three main centres of commercial and "industrial" development. On one side are the two great poles of trade: the Mediterranean (firstly the Arabi/Muslim area, the comeback of Italy and, to a lesser extent, the Provence and Spain) and the North (Slavo-Scandinavian area). To these it can be added the third centre: an intermediate economical and geographical pole 
between the above mentioned areas, the manufacture and trade zone of the North-West (eastern England, Normandy, Flanders, Champagne, Meuse and lower Rhineland).

The development of trade and business in the Western Europe has experienced a transition from travelling merchants (depending on the conditions and safety of transport routes, the number and attraction of periodical or permanent fairs, the privileges and protection) to the emergence of the sedentary merchant who, "at the headquarters of his business, he will guide and lead by more evolved methods and by the increasingly complex organization, a network of associates or employees..."(Le Goff, 1994: 39).

In the following part we will treat both the main forms of business organization (commenda, compagnia, limited partnerships, limited companies) and most representative forms of association of business (guilds and the Hanseatic League).

\subsection{Commenda and compagnia}

A main form of association was the commenda contract, where the contracting parties are considered to be related to the extent that they were involved in the risk and outcome of a specific action, but otherwise, the relationship remained as those between creditor and debtor.

There are two types of contracts in commenda: the ordinary and the special - societas maris or collegantia. In the first form, a general partner (comendas) acting as a passive investor, lends the itinerant merchant (comendatarius) the capital required for a remote business enterprise (Hansmann, et al, 2006). If the expedition ends in loss, the financial loss is fully supported by the lender, while the partner (the debtor under the loan), losing only the value of his work done on this occasion. If successful, the first (the lender, comendas) recovers their loan and receives a large part of the benefits.

Given that lenders did not agree to transfer the amounts lent in the personal property of the debtor (the itinerant merchant), the credit allocation was agreed only to carry out certain trading operation and for a certain period of time. This solution, however, had two consequences: on the one hand the capital borrowed forms a separate and autonomous patrimony of the general partners of limited partners and, and, on the other hand, this heritage has required the interposition of a third (to hold it). Thus was created an abstract legal entity - the company organized as a limited partner, born of the collective will of the limited and general partners/merchants, having its own assets and legal capacity under which he could exercise and assume obligations in its own name (Costin and Jejlea, 1999: 4). This legal arrangement has led to the concept of the company as a legal entity (Vonica, 2000: 30).

Benefits for the commenda contract go primarily to understanding the limited liability enjoyed by the passive partner, as the active partner intended to withdraw all claims to the assets of the passive partner (other than the initial investment) in case of the failure of business (Weber, 2003; Hickson and Turner, 2005). Along with the feature of limited liability, the commenda's novelty lies in the legal protection conferred to the partners, especially to the passive partner (Hansmann, et al, 2006). Finally, the third feature of the commenda is that it is able to reduce the costs of primary liquidation, which is done in medieval Italy in a similar form as today. Thus, the contribution of the passive partner (investment capital) could be divided into shares (partes; see also following paragraphs on shares companies) which could be sold or inherited or exploited in favourable moments (Weber, 2003). These three features have made the commenda a forerunner of modern enterprises.

This "primitive" form of company is maintained, perhaps because of its simplicity, even until the sixteenth century. It could be encountered at the merchants of Portugal, Dalmatia, Venice or the Hanseatic cities. Fernand Braudel cites a Reims merchant's opinion from 1665 , on this type of association: "... without doubt, you cannot do business with people who have no funds; because they share profits and all loss falls on you. However, there 
are enough businesses like this, but I do not advise this to anyone, ever "(Braudel, 1985: 85).

For the second form of commenda - societas or collegantia maris, the limited partner does not travel (socius stans - one who stands) borrows two thirds of capital required, and the traveling partner (socius tractator) the other third. The loss is be covered according to the invested capital, but the profits are shared equally between the two parties. Modern scholars see this intuitive division between financial capital and human capital as, from the beginning to end, the traveling partner would not participate at all in the capital, and would receive the equivalent value of his work (Bloch, 1962).

For onshore business, we find two main types of contracts of association: compagnia and societas terrae, which relates to transactions arising from expanding operations from major ports to inland traders. According to Fernand Braudel, the compagnia is above all a family company, which, as the name suggests, includes the father, sons, brothers and other relatives (con - with and panis - bread), being based on unity and responsibility of capital, labour and results (Braudel, 1985). Thereafter, it shall be called "the collective name" because all its members are jointly responsible, not only within the part that participated, but also to guarantee with all their goods.

Conditions, although resembling the societas maris in terms of borrower risk, become more flexible, shares can vary greatly, duration is not limited to a boat trip, but to a certain fixed period - a year or more; and the founders allow foreign associates other than family member. While earning power and accumulating capital, - far beyond the initial capital deposited, they become true capitalist tools, long before historians mark the beginning of this period. Around the families of merchants are formed complex organisms, called "companies" because they do not disappear at originator's death, but are re-established. They are the so-called "trading houses", led by the illustrious Florentine families Bardi, Peruzzi, Medici (Le Goff, 1994: 25).

The periodical renewal of the association and trade contracts, their presence in vast economic zones, their persistent pursuit of business interests through a network of commercial contacts, gradually transforms these companies into stable bodies.

The $14^{\text {th }}$ and $15^{\text {th }}$ centuries know an expansion and decentralization of these traders. In addition to the headquarters, they also owned or managed several branches and employees in different cities, each with its own capital and directors, often acting as business associates.

Characteristic to $14^{\text {th }}-16^{\text {th }}$ centuries, this type of company failed to adapt to new tools and methods that accompany the expansion over the Atlantic and the beginning of the great geographical discoveries of modern times. However, this "Florentine" type of company extensive, stable, and, especially connected relating to a certain family, had recovered and reconstituted periodically, as needed, shareholders or opportunities (Braudel, 1985).

\subsection{Limited partnerships and joint stock companies in the Middle Ages}

The general partnership didn't fully satisfy neither the requirements of capital expansions, nor subjective interests of some participants in the business, who wanted to be responsible only for financial contribution made in a company. This limited liability arises, according to historical sources, in Florence, in the early part of the sixteenth century and is expanding gradually in France and then in England (Braudel, 1985; Braudel, 1989). The progresses of the limited partnership - both an association of people and an association of capital during the $16^{\text {th }}$ and $17^{\text {th }}$ centuries in Europe, are slow but steady, benefiting from a few advantages. Thus they provide the (partial) substitution of family ties, (compagnia, general companies, and general partnerships). Secondly, it achieves a better fit of the business relationships between partners less known to each other or located in different cities, or between those who wanted to be least visible. Thirdly, they served business ties established between large retailers from the Atlantic ports of Europe, senior officials of the colonies in America, Africa and Asia, and the shipmasters that needed to be equally 
interested and controlled, but also protected from public exposure. Fourth, they provided protection against forfeiture of rank that threatened the nobles investing in commercial business, and helped hide the interests of the crown representatives in some businesses they already controlled (Pacala, 2012).

Unlike limited partnerships, the limited companies appear to be only joint equity where shareholders hold shared parts of this capital, the so-called "share". Officially, the first joint stock company in European history was the Moscovy Company (Braudel, 1985), established in 1553-1555 in England, but earlier forms of this type of company, with transferable shares could be met in the $12^{\text {th }}$ and $13^{\text {th }}$ centuries in the case of ships traveling the Mediterranean area (Venice, Genoa and Marseilles), of the mines in Sweden, France, Italy or Austria, or of the windmills in Belgium, France or Germany. They were taken by nobles or merchants, and the property was divided into transferable parts.

It should be noted that these early forms of shared capital are not widely accepted by historians and economists as joint stock companies, due to the reduced possibility of trading the shares, and the lack of a public market. Most of these parts ("share") were sold in a limited framework, like real estate transactions. With the exception of large companies which have used this form of partitioning shares (since the $16^{\text {th }}$ and $17^{\text {th }}$ centuries) to finance their expansion, in most European countries the joint stock company has a difficult start, and brings together a small number of companies, of minor importance. Finally, the idea of trading shares ran hard in businesses or investments habits; the term "shareholder" was accompanied by an unfavourable connotation, similar to that of "rentier".

\subsection{Guilds - forms of association of manufacturers and traders in the Middle Ages}

Guilds are a very old phenomenon; official associations of traders could also be encountered in the ancient world. In medieval Europe it seems that they could have formed as early as the seventh century AD, but most sources give us the image of a phenomenon of traders associations (more or less official) only from the $11^{\text {th }}$ century (Braudel, 1985).

There is quite little information about the functioning of trade guilds in medieval Europe in the $11^{\text {th }}$ and $12^{\text {th }}$ centuries. We have fragmentary evidence about the "brotherhood" of itinerant merchants who traded with the German Länder and the Netherlands, and some of these guild members pledged to help each other in case of fraud, violence or personal hardship. Much better documented are the commercial organizations of Africans Jews, the Maghribi, in the Mediterranean, during the late eleventh century, that transact with the Italian ports and have created social bonds, strong and credible enough to exclude from their trade those members who had cheated an Italian trading partner (Braudel, 1985).

Guilds in the $12^{\text {th }}$ and $13^{\text {th }}$ century were more numerous and more powerful, many of them having received official recognition from the local or central authorities throughout Europe. This was true not only for local traders and craftsmen organizations, but also for international trade guilds who received privileges either from the seniors of their native land, or from the authorities of the host country. Dessi and Ogilvie (2004) consider guilds as rent-seeking companies, being awarded privileges in exchange for financial support to the lord or king; therefore steadily reducing social welfare.

There is a large number of studies done on the trade and business communities, in almost every part of Europe, illustrating the multiplicity of functions that these institutions could meet: organization of trade and monetary circulation, protection against theft, civil unrest and violence, concentration of trade offices of foreign merchants, efforts to meet the demand and supply, development of rules regarding the quantity and quality of their products, supporting the development of means of transport and training of apprentices.

Merchant guilds contributed to ensuring the implementation (enforcing) of contracts. The privileges granted by local or foreign leaders have sworn guild leaders with the authority to resolve disputes between members. In addition, in the "corporate" world of the Middle Ages, the official membership in a guild (in a city or country) was a sign of someone's 
creditworthiness to potential trading partners, a collective responsibility to ensure (at least morally) a creditor to recover an overdue debt (Boerner and Ritschl, 2008).

Guilds with a good internal organization were able to provide protection against ruinous abuses from the landlords or kings. It is important to note that the city authorities were probably more interested than the central government in providing such protection in preindustrial Europe (Braudel, 1986; Gelderblom and Grafe, 2008; Trivellato, 2009).

The activity of guilds contributed to the development of other institutions or to the supply of public goods and services (storage, currency exchange, custody, protection etc.). Even if the net benefit was immediate for the guilds, these public goods and services have created positive spillovers to other market actors who were not necessarily part of the guild. In the perspective of Coase and Williamson, guilds can be understood through their engagement in collective action in order to minimize transaction costs (Gelderblom and Grafe, 2008).

At first glance we can expect that guilds to have lost their raison d'être in the $15^{\text {th }}$ and $16^{\text {th }}$ centuries, when European political leaders have become increasingly engaged in the creation of law courts, in protection of trade, elimination of special privileges etc. However, strengthening the political, economic, and legal control over their territories was accompanied by military conflicts between states, leading to an increase of violence against traders over long distances, at least on the medium term. As a result, merchants in many parts of Europe continued to act collectively to achieve their trade routes' safety (Lane, 1958; Gelderblom and Grafe, 2008).

The political fragmentation of Europe has contributed to the persistence of merchant guilds in yet another way. The host country authorities and businesses, being interested in continuing external financial flows, would grant foreign trade associates consular jurisdictions. This is the explanation of the existence of merchant associations in Bruges and Antwerp, in southern France during the mid-sixteenth century, the consulates of British and Dutch traders in Russia and the Ottoman Empire during the eighteenth century (Gelderblom and Grafe, 2008).

However, commercial guilds embraced the decline in pre-industrial Europe, the $17^{\text {th }}$ and $18^{\text {th }}$ centuries recording a clear departure from the Middle Ages-specific forms of traders' associations (Gelderblom and Grafe, 2008; Greif, 1997).

Guilds survived symbolically in numerous social and business issues. The business community, formally or informally, continued to provide diplomatic, educational, religious or social assistance to its members, facilitated business and social contacts between foreign traders and the local populace, recruiting among them local authorities, notaries, military personnel, relying on members' attachment to the group, loyalty or revival of traditions, etc.

\subsection{The German Hansa - the main association of traders in northern Europe}

Although at its apex the German Hansa (or Hanseatic League) defined itself as a confederation of cities, it began as an association of individual merchants, most researchers agreeing with Philippe Dollinger's statements referring to the first phase of the history of the Hanseatic as the "Hansa of merchants "(Lloyd, 1991). In the $13^{\text {th }}$ century, the free associations of German merchants evolved into the "Hansa of Cities", which became relatively quickly, a redoubtable economic and political power in northern Europe. The Hanseatic League's size and strength were directly dependent on the number of cities which have joined. At its peak, nearly 200 cities were included in the Hansa, with an additional four trading centres (so called Kontore) in London, Bruges, Bergen and Novgorod (Lloyd, 1991). In the history of the Hanseatic League, the role of leadership, since the establishment of the League in 1159 and until its end, was assumed by the German city of Lübeck (Dollinger, 1970: 214). In the middle of the $13^{\text {th }}$ century, during the transition from the "Hansa of merchants" to the "Hansa of cities", many of these cities had agreed to share the costs of maintaining road safety between them, united resistance against pirates and mutual assistance in time of war (Schildhauer, 1988: 40). 
The community of merchant cities clustered around the German Hanseatic League controlled during the Middle Ages most of the trade in the Baltic Sea and, to a lesser extent, in North Sea. Generally, hanseatic merchants were transporting raw materials from the Baltic and Eastern Europe to Western Europe, and returning with manufactured and luxury goods (Dollinger, 1970: 214). Goods sold by the merchants of the Hanseatic League included fine cloth from England and the Netherlands, furs and wax from Novgorod and Livonia, salted herring from southern Sweden, salt from France, lumber and grain from Poland and Prussia, beer and linen from Germany, wines from Spain, France and the Rhineland, Prussian amber, copper and iron from Sweden (Franson, 2000). Although it was willing to use military force to maintain and develop business, the Hansa generally preferred to use peaceful tactics - diplomacy, boycotts and trade embargoes. The Hanseatic League was unique among the political entities of its time because it had no interest in the annexation of territories. Instead, it "continuously fought for its commercial interests" (Schildhauer, 1988).

For the Hansa, the $15^{\text {th }}$ century marks the beginning of a slow and lasting decline, due to various factors, both internal and external. One factor was the increasing competition from British and Dutch traders, supported by political leaders in the countries of origin. Secondly, against the consolidating monarchical powers in northern Europe, particularly in Northern Europe and the Netherlands, the Hanseatic League was in obvious disadvantage, the old "economic" tactics, such as embargoes and threats to suspend commercial relations, which had been effective against minor cities and principalities, proving to be ineffective against large and powerful states (Dollinger, 1970: 281), and the prospect of military action against these powers was even less feasible.

Increased involvement of monarchs in the governance of their states proved to be a growing threat; the princes of many German states viewed the Hansa as "a serious obstacle to strengthening their local sovereignty" (Schildhauer, 1988), pressing Hanseatic cities in their territories to exit the Hanseatic League. Internal factors, such as conflicts both within and between the Hansa's cities contributed to weakening the League. Inability or refusal to present a united front for tough economic actions, such as boycotts and embargoes, expressed a clear misunderstanding between cities, and became a serious threat to the power of the Hansa (Franson, 2000).

The Hanseatic League survived, in one form or another, until the end of the eighteenth century, overcoming wars, and alternating periods of withdrawal to regain its international status. Despite postponing their decline, the economic and political realities did not fit to the medieval structure of the organization, the last General Hanseatic Council (Hansetag) taking place in 1669 (Dollinger, 1970: 368).

\section{Conclusions}

With all their diversity (in terms of size, complexity, geographical expansion, ownership or management), contemporary companies take, in varying proportions, elements of Roman law and especially of the distinct experiences of the Middle Ages and the modern period. Overwhelmed by the remarkable achievements of the Roman world, we perceive as unusual that the majority of Roman companies seem to have not been endowed with legal personality, protected by the law. The exception consisted of a small group of large firms, which only provided services to the Roman state and in which one could recognize (although with uncertainty and limitations) the prototype of today's large corporations (Badulescu \& Badulescu, 2008). Far from being a "dark" century, the extended medieval period generated the classical forms of organizing companies, joint stock companies, limited partnerships, partnerships and so on. In a more perfected form, they endure until today, but history also records other organizations, although typical of that time, yet nowadays fallen into disuse and oblivion for the dynamic capitalist economy, but not for passionate researchers. 
An important lesson taught by this historical episode is to not ignore the social and political conditions, as well as the legislative framework permitted by the society. Heirs in different, but determinant combinations of the incomparable Roman law, of the adaptability and innovation of the capitalism arisen at the dawn of the Middle Ages, we can find in history lessons and solutions to the problems of contemporary society and economy.

\section{References}

Badulescu, D. and Badulescu, A. (2008). 'Theoretical Background of Corporate Governance (I)'. Annals of the Oradea University, Fascicle of Management and Technological Engineering, vol. VII, no. XVII, pp. 1886-1890.

Badulescu, D. and Badulescu, A. (2008). 'Theoretical Background of Corporate Governance (II)'. Annals of the Oradea University, Fascicle of Management and Technological Engineering, vol. VII, no. XVII, pp. 1891-1895.

Bloch, M. (1962). Feudal Society. Volume 1: The Growth of Ties of Dependence. London and New York: Routledge \& Kegan Paul Ltd.

Boerner, L. and Ritschl, A. (2008). The Economic History of Sovereignty: Communal Responsibility, the Extended Family, and the Firm. [Online] Available at: http://www2.Ise.ac.uk/economicHistory/Conferences/States\%20and\%20Growth/BoernerRit schl.pdf, [19 Jan 2016].

Braudel, F. (1985). Jocurile schimbului/The Wheels of Commerce. Bucureşti: Editura Meridiane.

Braudel, F. (1986). Mediterana şi lumea mediteraneană în epoca lui Filip al II-lea/ The Mediterranean and the Mediterranean World in the Age of Philip II. Bucureşti: Editura Meridiane.

Braudel, F. (1989). Timpul lumii/The Perspective of the World. Bucureşti: Editura Meridiane.

Costin, M. and Jejlea, C. (1999). Societăţile comerciale de persoane. Bucureşti: Editura Lumina Lex.

Crook, J. (1967). Law and Life of Rome. Ithaca, New York: Cornell University Press.

Dessì, R. and Ogilvie, S. (2004). 'Social Capital and Collusion: The Case of Merchant Guilds'. Cambridge Working Papers in Economics, Vol. 417.

Dollinger, P. (1970). The German Hansa. London: Macmillan, 1970

Franson, J. (2000). Zenith and Decline: The Hanseatic League and the Teutonic Order in the Late 14th and Early 15th Centuries. [Online] Available at: http://www.troynovant.com/Franson-JM/Essays/Hanseatic-Teutonic.html, [10 Dec 2015].

Gelderblom, O. and Grafe, R. (2008). The Rise, Persistence and Decline of Merchant Guilds. Re-thinking the Comparative Study of Commercial Institutions in Pre-modern Europe. [Online] Available at: http://www.econ.yale.edu/seminars/echist/eh09/grafe090413.pdf, [09 Oct 2013].

Greif, A. (1997). Self-enforcing Political System and Economic Growth: Late Medieval Genoa. [Online] Available at: http://www-siepr.stanford.edu/workp/swp97037.pdf, [21 Nov 2015].

Hansmann, H. and Kraakman, R. (1999). Organizational Law as Asset Partitioning. Ann Arbor, Michigan, Working Paper No. 252, Conference on Corporate Governance at The Davidson Institute.

Hansmann, H., Kraakman, R. and Squire, R. (2006). 'Law and the Rise of the Firm'. Law Working Paper No.57, Vol. 57.

Hickson, C. \& Turner, J. (2005). Partnership. Encyclopedia of World Trade since 1450. New York: Macmillan.

Johnston, H. (1932). The Private Life of the Romans. Scott, Foresman and Company. Lane, F. (1958). 'Economic Consequences of Organized Violence'. The Journal of Economic History, vol. 18, no. 4, pp. 401-417. 
Le Goff, J. (1994). Negustorii şi bancherii în evul mediu/ Merchants and Bankers in the Middle Ages. Bucureşti: Editura Meridiane.

Lloyd, T. (1991). England and the German Hanse, 1157-1611. Cambridge University Press.

Malmendier, U. (2005). 'Roman Shares'. In: W. Goetzmann \& K. G. Rouwenhorst, eds. The Origins of Value: The Financial Innovations that Created Modern Capital Markets. Oxford University Press, USA.

Malmendier, U. (2006). Law and Finance "at the Origin". [Online] Available at: http://emlab.berkeley.edu/users/webfac/cromer/e211 sp07/malmendier.pdf, [09 Jan 2016].

Pacala, A. (2011). 'The Evolution of The Company-Idea as a Distinct Form of Separation an Protection for Business in Antiquity'. Journal of Electrical and Electronics Engineering, Vol. 4, No. 2, pp. 77-82.

Pacala, A. (2012). Intreprinderea: repere evolutive și dimensiuni actuale. transformări și performanțe în sistemul corporativ românesc după 1989/The Company: Evolutive milestones and current dimensions. Transformation and performance in Romanian corporate system after 1989, Doctoral Thesis, Oradea: University of Oradea.

Schildhauer, J (1988). The Hansa: History and Culture. New York: Dorset Press.

Trivellato, F. (2009). The Familiarity of Strangers: The Sephardic Diaspora, Livorno, and Cross-Cultural Trade in the Early Modern Period. Yale University Press.

Vonica, R. (2000). Drept comercial. Partea generală. Bucureşti: Editura Lumina Lex.

Weber, M. (2003). The History of Commercial Partnerships in the Middle Ages (1889). Lanham: Rowman \& Littlefield.

\section{Bio-note}

Anca Păcală has a degree in Law and a PhD in Economics. Currently she holds the positon of lecturer at University of Oradea, being member of several research teams. Her main interests refer to corporate and commercial law, and corporate governance. 